\title{
Review of serum prolactin levels as an antipsychotic- response biomarker
}

\begin{abstract}
Antipsychotics acting as antagonists at dopamine D2 receptors concentrated in the striatum are the cornerstone of effective treatment of psychosis. Substantial progress in treating persons with schizophrenia could be achieved by the identification of biomarkers which reliably determine the lowest efficacious dose of antipsychotics. Prolactin levels have been considered a promising treatment-response biomarker due to dopamine's regulation of serum prolactin levels through D2 receptors in the hypothalamic-pituitary pathway. Prolactin secretion in response antipsychotic administration is associated with the antipsychotics affinity for D2 receptors. This review assesses the available literature on the use of serum prolactin levels as an antipsychotic-response biomarker. Articles were identified through PubMed as well as the reference lists of full text articles available online. Relevant publications were summarized briefly to define the limitations and utility of serum prolactin levels as a tool for improving antipsychotic dosing. Serum prolactin levels in combination with prolactin-inducing potencies for each antipsychotic may help identify the lowest effective dose of antipsychotic medications. , In addition to the fact that prolactin secretion is dependent on serum antipsychotic levels and not brain levels, recent findings show that prolactin release is independent of the $\beta$-arrestin- 2 pathway and GSK3 $\beta$ regulation, one branch of the pathway that has been implicated in antipsychotic efficacy. Therefore, serum prolactin is an indirect biomarker for treatment response. Further investigations are warranted to characterize prolactin-antipsychotic dose-response curves and systematically test the utility of measuring prolactin levels in patients to identify a person's lowest efficacious dose.
\end{abstract}

Keywords: antipsychotic, dopamine, biomarker, prolactin, dose response, schizophrenia, psychosis, serum
Volume 2 Issue 3 - 2018

\author{
Judith M Gault, ${ }^{1,2}$ Abraham M Nussbaum ${ }^{1,3}$ \\ 'Departments of Psychiatry, University of Colorado Denver, \\ Anschutz Medical Campus, USA \\ ${ }^{2}$ Departments of Neurosurgery, University of Colorado Denver, \\ USA \\ ${ }^{3}$ Denver Health, USA
}

Correspondence: Judith Gault, Departments of Psychiatry, Anschutz Medical Campus, Anschutz Medical Campus, 12700 E. $1^{\text {th }}$ Ave, Box 860I, Aurora, CO 80045, USA, Email Judith.gault@ucdenver.edu

Received: October 29, 2017 | Published: May 04, 2018
Abbreviations: AKT1, alpha protein kinase serine/threonine kinase 1; BBB, blood brain barrier; BPRS, brief psychiatric rating scale; CDK5, cyclin dependent kinase 5; D2, dopamine D2 receptor; GSK3 $\beta$, glycogen synthase kinase 3 beta; PRKACA, protein kinase camp-activated catalytic subunit alpha; PP1, protein phosphatase 1 catalytic subunit alpha; PPP1R1B, protein phosphatase 1 regulatory inhibitor subunit $1 \mathrm{~b}$; SZ, schizophrenia; GABA, $\gamma$-aminobutyric acid

\section{Introduction}

The current standard of care for optimizing antipsychotic dose relies on titration within a recommended dose range while subjectively assessing how symptoms respond to dose changes. ${ }^{1}$ Using this general approach to dose finding, antipsychotics are clearly efficacious and are fundamental to treatment success for persons with schizophrenia. Antipsychotic clinical response is high; for example, $94 \%$ of firstepisode patients who are hospitalized with SZ clinically respond to olanzapine or risperidone. ${ }^{2,3}$

Over $90 \%$ of subjects in clinical trials experience significant (50-70\%) to minimal improvement (20-30\%) on antipsychotics and $10-20 \%$ show no improvement or decline without a significant difference between first- and secondgeneration antipsychotics, with the exception of clozapine. ${ }^{4-6}$ Antagonistic action at dopamine D2 receptors, found at their highest concentration in the striatum, is essential to antipsychotic action (Figure 1A). Nevertheless, currently available treatments have several notable limitations. Antipsychotics have similar efficacy with the exception of the most effective antipsychotic, clozapine. ${ }^{7-9}$ A multicenter clinical trial showed that
$74 \%$ of the patients enrolled discontinued their medication because of poor efficacy and intolerable adverse effects. ${ }^{6}$ Even when compliant with medications, patients relapse at a rate of $27-35 \%$ per year even when compliant with medication. ${ }^{1,10}$ Antipsychotics provide symptomatic relief, but are not curative, and are sometimes inadequate even when an optimal dose is administered.

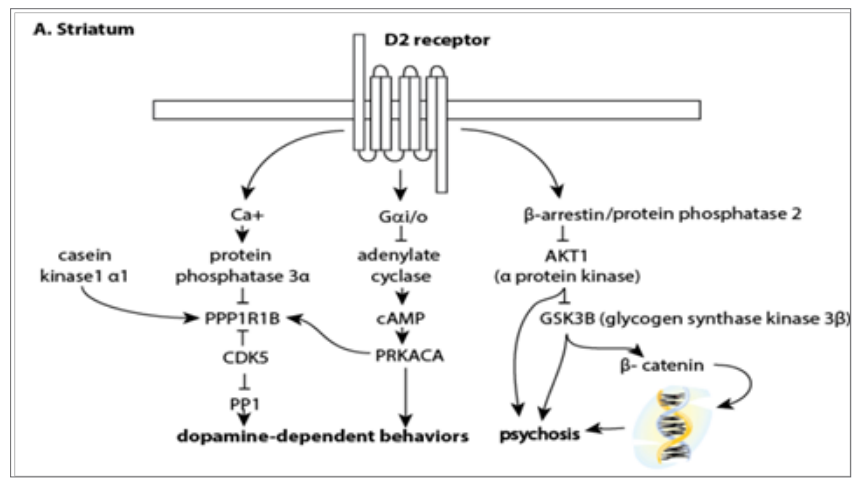

Figure I (A) The D2 receptor pathway found in the striatum. The $\beta$-arrestin pathway has been shown to contribute to antipsychotic effect.

Therefore, patients may be subjected to excessive doses that increase adverse effects without additional therapeutic efficacy. It is established that a specific antipsychotic dose will result in variable patient response and 45 -fold differences in drug levels in the plasma. ${ }^{11}$ Most antipsychotic are readily absorbed through the gastrointestinal 
tract, are metabolized by various cytochrome $\mathrm{P} 450$ enzymes primarily in the liver, and are highly bound by plasma proteins. ${ }^{12}$ Antipsychotics are lipophilic and readily cross the blood brain barrier (BBB) to concentrate possibly 10-20 times higher in the brain. While measuring plasma levels of the mood stabilizer, lithium, has been successful in maximizing efficacy and minimizing adverse effects, monitoring blood levels of antipsychotics has been less successful and conflicting studies have made it difficult to establish guidelines for the efficacious range of antipsychotic therapeutic serum concentrations. ${ }^{13,14}$ Several studies have shown that a $64-80 \%$ response rate is achieved after 6 months at plasma levels of clozapine of greater than $350-450 \mathrm{ng} /$ $\mathrm{mL} \cdot{ }^{11,15-17}$ For other antipsychotics, the range of clinically efficacious plasma levels is not agreed upon and study results areinconsistent or requires further confirmation. At present, plasma levels are helpful as proxies for medication adherence, demonstrating that a reasonable level is found in nonresponders, and avoiding toxicity, but have not been useful for optimizing an efficacious dose.

While further investigation into efficacious serum concentrations for antipsychotics is conducted, additional objective measures are needed to identify the lowest efficacious dose while minimizing adverse effects. This paper assesses the potential use of serum prolactin levels to determine the optimal dose of some antipsychotic medications and the lessons learned from measuring prolactin levels with antipsychotic treatment.

\section{Discussion}

\section{Prolactin biology}

Discovered in humans in the early 1970 ' $\mathrm{s}^{18}$ prolactin is a $23 \mathrm{kDa}$ polypeptide hormone predominantly synthesized and secreted by the lactotroph cells of the anterior pituitary into the third ventricle. ${ }^{19}$ The release of prolactin from the pituitary is regulated by the hypothalamus and a complex array of feedback mechanisms. The release of prolactin is stimulated by substances like oxytocin and thyrotropin releasing factor, but inhibited by dopamine, somatostatin, and $\gamma$-aminobutyric acid (GABA) and prolactin itself. The pituitary contributes primarily to prolactin levels and primates and rats with their pituitary removed have an $80-95.4 \%$ reduction in serum prolactin. ${ }^{20,21}$ Dopamine is the main factor inhibiting prolactin release. Dopamine receptors on the cell membranes of lactotrophs are primarily D2 dopamine receptors (Figure 1B). Dopamine neurons project from the dorsomedialportion of the hypothalamus's arcuate nucleus to the external zone of the anterior pituitary's median eminence along the tuberoinfundibular pathway, delivering dopamine through the portal circulation into the sinusoid capillaries of the anterior lobe. ${ }^{22}$ When the release of dopamine is disrupted or its activity on the anterior pituitary is blocked, prolactin is released into the systemic circulation. Serum prolactin studies are widely available at clinical laboratories. The prolactin assay is performed on serum, in a serum separator tube within forty minutes of the blood draw. The test costs approximately fifteen dollars and normal levels range from $1-25 \mu \mathrm{g} / \mathrm{L}$ for women and $1-20 \mu \mathrm{g} / \mathrm{L}$ for men. ${ }^{23}$

The release of dopamine from the tuberoinfundibular pathway is inhibited by cholecystokinin-8, endogenous opioid peptides, estrogen, galanin, histamine, nitrous oxide, norepinephrine, serotonin, somatostatin, and $\gamma$-aminobutyric acid. The release of dopamine from the tuberoinfundibular pathway is stimulated by acetycholine, angiotensin II, atrial natriuretic peptides, bombesin-like peptides, calcitonin, neuropeptide Y, glutamate, neurotensin, oxytocin, thyrotropin releasing factor, vasoactive intestinal polypeptide, and vasopression..$^{22}$ The clinical implication is that because the release of prolactin is influenced by so many neurotransmitters and hormones, serum prolactin can be elevated by multiple drugs often used by people with mental illness including agents that increase serotonin, including tricyclic antidepressants and selective serotonin reuptake inhibitors, drugs that antagonize histamine receptors, like cimetidine and ranitidine, hormones in oral contraceptives, and drugs of abuse, including alcohol and opiates. ${ }^{24}$

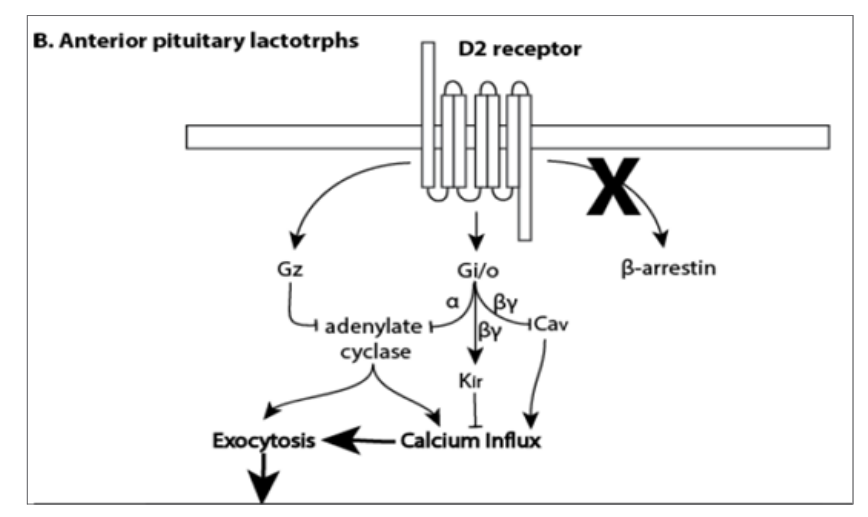

Figure 1 (B) The D2 pathway found in the anterior pituitary. Prolactin secretion occurs through dopamine D2 receptors through $\mathrm{G}(\mathrm{i} / \mathrm{o})$ proteins that block voltage-gated $\mathrm{Ca}(2+)$ influx and $\mathrm{G}(\mathrm{z})$ signaling by desensitizing $\mathrm{Ca}\left({ }^{2+}\right)$ secretion. The D2/ $\beta$-arrestin-2 pathway involving GSK3 $\beta$ does not appear to be involved in prolactin release.93-95 AKT1, alpha protein kinase serine/ threonine kinase 1, CDK5, cyclin dependent kinase 5; GSK3 $\beta$, glycogen synthase kinase 3 beta; PP1, protein phosphatase 1 catalytic subunit alpha; PPP1R1B, protein phosphatase 1 regulatory inhibitor subunit 1B; PRKACA, protein kinase cAMP-activated catalytic subunit alpha.

\section{Antipsychotic induced hyperprolactinemia}

Antipsychotics bind to the short (presynaptic autoreceptor), long (post synaptic) and the longer (less abundant) forms of D2 receptors ${ }^{25,26}$ to lower dopaminergic tone in the meso-cortical and meso-limbic pathways and treat the psychotic symptoms of SZ. ${ }^{27-31}$ Although D2 receptors have a high-affinity and low-affinity state, most D2 receptors are in the high affinity state, the state where antipsychotics bind..$^{32}$ Dopamine acting on D2 receptors is inhibitory and $\mathrm{D} 2$ receptors are at highest levels $(16.5 \mathrm{pmol} / \mathrm{g}$ tissue $)$ primarily on medium spiny neurons in the striatum.

Many adverse effects of antipsychotic use are due to antagonism at D2 receptors in the nigro-striatal pathway (parkinsonian, extrapyramidal side effects) and the tubero-infundibular (prolactin) pathway. ${ }^{33,34}$ Regions of the tubero-infundibular pathway have D2 receptors levels are 1.3 to $1.8 \mathrm{pmol} / \mathrm{g}$ tissue in the pituitary and hypothalamus respectively. ${ }^{35}$ Prolactin released by other regions of the brain, lymphocytes and other organs is thought to contribute up to $20 \%$ total prolactin levels than the anterior pituitary and it is currently not known whether these secondary sites are also altered by high affinity D2 antagonism. Hyperprolactinemia is defined by prolactin levels above $15-18.77 \mathrm{ng} / \mathrm{ml}$ for males and $23-24.20 \mathrm{ng} / \mathrm{ml}$ in females. ${ }^{36-38}$

There is conflicting evidence that prolactin levels maybe elevated during acute psychosis. Prolactin levels were elevated 2.3-fold (15.1 and $35.1 \mathrm{ng} / \mathrm{ml}$ in men and women respectively) in 33 antipsychoticnaïve subjects with $\mathrm{SZ}(\mathrm{n}=18)$, brief psychotic disorder $(\mathrm{n}=9)$, schizophreniform disorder $(\mathrm{n}=3)$ and unspecified psychosis $(\mathrm{n}=3) .{ }^{39}$ However, a 2.1-fold decrease in serumprolactin levels was found in 
30 male hospitalized patients with SZ at baseline possibly in response to antipsychotic withdrawal during the 2 -week wash out period. ${ }^{40}$ In another study prolactin levels were found at the high end of normal at baseline ( 18.2 and $23.5 \mathrm{ng} / \mathrm{ml}$ for men and women respectively) in 27 acutely psychotic patients with SZ when they were medication-naïve or medication-free for at least 4 weeks. ${ }^{41}$ One might expect subjects experiencing psychosis to have low prolactin levels if psychosis is related to excessive dopamine stimulation at the D2 receptors or because psychosis causes a lack of sleep. Increased prolactin levels have been implicated as one of $51 \mathrm{SZ}$ diagnostic biomarker for treatment naïve subjects. ${ }^{42}$ In 14 postmortem brains from SZ subjects, prolactin levels were reduced by $46 \%$ relative to controls although

only one of the two assessments were found significant. ${ }^{43}$ These findings warrant further investigation to determine whether prolactin levels are elevated in relation to physical/emotional stress during psychosis or if they are generally elevated in treatment-naïve subjects with SZ. The prevalence of hyperprolactinemia when taking prolactinraising antipsychotics is $65.6 \%$ in women of reproductive age, $45.1 \%$ in postmenopausal women and $42.4 \%$ in men. ${ }^{38}$

Hyperprolactinemia is potentially associated with amenorrhoea, galactorrhoea, sexual dysfunction, ${ }^{44}$ breast engorgement, and osteoporosis..$^{37,45}$ Neuroscientists began investigations into prolactin levels as an indicator of hypothalamic activity during psychiatric illness ${ }^{19}$ and following the observation in animals that many antipsychotics stimulate prolactin secretion ${ }^{46,47}$ consistent with prolactin levels being an indicator of dopamine blockade and generating the hypothesis that increased serum prolactin levels were associated with antipsychotic clinical efficacy. However, prolactin levels are inconsistently correlated to efficacy; for example clozapine is the most efficacious antipsychotic, but it does not cause a sustained increase in prolactin levels (Table 1). ${ }^{48,49}$ Prolactin levels cannot be used to predict who will be responsive to antipsychotic drugs even though they might be helpful in determining if a dose is too low. The potential use of prolactin as a measure of neuroleptic bioavailability and central nervous system activity was the focus of a review article in $1983 .^{50}$ Brown summarized compelling evidence that showed an association between prolactin levels with antipsychotic dose in 26 men with SZ being titrated off neuroleptics, "fairly consistent" findings of correlations of $0.83 / 0.92$ between prolactin and haloperidol/ chlorpromazine levels throughout the therapeutic range, studies showing low serum prolactin levels in patients that had relapsed, a $20-25 \%$ variability in an individual's prolactin levels when they are a constant dose and that "serum prolactin is far more affected by dose, serum level and individual differences than by physiological adaptive changes of tolerance" ${ }^{50}$ In a preliminary study done in patients with SZ, genetic variation at the prolactin and prolactin receptor loci were not associated with: 1) prolactin serum levels $;{ }^{51}$ 2) patients who do not respond to antipsychotic treatment; or 3) patients who have tardive dyskinesia. ${ }^{52}$ Serum prolactin levels are primarily under dopaminergic control and increase in response to D2 antagonists such as haloperidol, blockade of monoamine transporters that decrease extracellular dopamine such as reserpine, but do not change significantly in response to partial D2 agonists such as aripiprazole. ${ }^{53}$

\section{Antipsychotic-specific induction of prolactin levels}

Compelling evidence supporting a correlation ( $\mathrm{r} 2=0.52)$ between the prolactin inducing potency (Table 1) and lowest effective antipsychotic dose using 19 antipsychotics was identified by extrapolating to a haloperidol dose-prolactin increase response curve. ${ }^{54}$ The potential use of antipsychotic-induced serum prolactin levels as a biomarker of the lowest effective dose of antipsychotic was identified in $95 \%$ of the studies examined presented. ${ }^{54}$ De Visser et al. recommended generating doseprolactin response curves specific to each antipsychotic. They did not discuss whether prolactin levels could be helpful for identifying an individual's lowest effective dose as proposed here (Figure 2 A) \& (Figure 2 B) ${ }^{54}$ Relying on studies reporting Risperidone, amisulpride and paliperidone have the greatest risk (80-90\% of females) for hyperprolactinemia followed by first generation medications ( $75 \%$ risk) then other second-generation antipsychotics have lower and less sustained effects olanzapine ( $78 \%$ risk) then ziprasidone ( $73 \%$ risk) then quetiapine (59\% risk) and clozapine. ${ }^{45,55}$ Aripiprazole, a partial D2 agonist has no effect on prolactin levels and can be used to reduce prolactin levels. ${ }^{56,57}$

Table I Summary of select antipsychotic drugs on prolactin levels

\begin{tabular}{|c|c|c|c|c|c|c|}
\hline Drug & $\begin{array}{l}\text { Dose } \\
\text { range } \\
\text { mg/day }\end{array}$ & $\begin{array}{l}\text { Protein } \\
\text { binding }\end{array}$ & $\begin{array}{l}\text { Active } \\
\text { metabolite }\end{array}$ & $\begin{array}{l}\text { Half-life } \\
\text { hrs/steady } \\
\text { state days }\end{array}$ & $\begin{array}{l}\text { Prolactin-inducing dose } \\
\text { equivalents }(54) / \text { induces } \\
\text { hyperprolactinemia }\end{array}$ & $\begin{array}{l}\text { Striatum D2 occupancy } \\
\text { (mg/day)striatum }\end{array}$ \\
\hline Amisulpride & $300-1200$ & & & & $56.6 /$ Yes & $85 \%(83)$ \\
\hline $\begin{array}{l}\text { Aripiprazole } \\
\text { (Partial Agonist) }\end{array}$ & $10-30$ & $98 \%$ & Dehydo-ARIP & $75-146 / 14$ & $-/ \mathrm{No}(53)^{*}$ & $\begin{array}{l}50-94 \%(5-50-94 \%(5-30) \\
(83,84)\end{array}$ \\
\hline Chlorpromazine & $30-300$ & $>90 \%$ & none & 30 & $39.6 /-$ & \\
\hline Clozapine & $300-900$ & $97 \%$ & norclozapine & $12 / 3-4$ & $309 /$ No $(49,85)$ & $30-70 \%(100-800)(83,86,87)$ \\
\hline Fluphenazine & $2.5-40$ & $\mathrm{~N} / \mathrm{A}$ & $\mathrm{N} / \mathrm{A}$ & N/A & $1.89 /$ Yes & \\
\hline Haloperidol & $1-15$ & $92 \%$ & none & 3 weeks/ 100 & $1.11 /$ Yes & $60-91.9 \%(2-5)(73,83)$ \\
\hline Loxapine & $60-250$ & $\mathrm{~N} / \mathrm{A}$ & none & 4 & $-/ Y e s(72)$ & $60-80 \%(15-30)(88)$ \\
\hline Olanzapine & $5-20$ & $93 \%$ & none & $20-70 / 7$ & -/No (49) & $60-96.5 \%(5-40)(83,86,89)$ \\
\hline Quetiapine & $300-400$ & $80 \%$ & none & $1.5 / 2-3$ & $-/$ No (49) & $49.1-64 \%(150-600)(83,90)$ \\
\hline Risperidone & $2-8$ & $89 \%$ & paliperidone & 20 & $0.1 / \operatorname{Yes}(49)$ & $65->92.4 \%(2-6)(83,86,91)$ \\
\hline Ziprasidone & $40-160$ & $>99 \%$ & none & $5-10 / 1-3$ & $-/ \mathrm{No}(92)$ & $82.9 \%(83)$ \\
\hline
\end{tabular}

*Fold change over baseline vs after medication in healthy controls, M: male and F: female

Association of prolactin levels with antipsychotic dose.

Timing and duration of prolactin response to antipsychotic dose. 


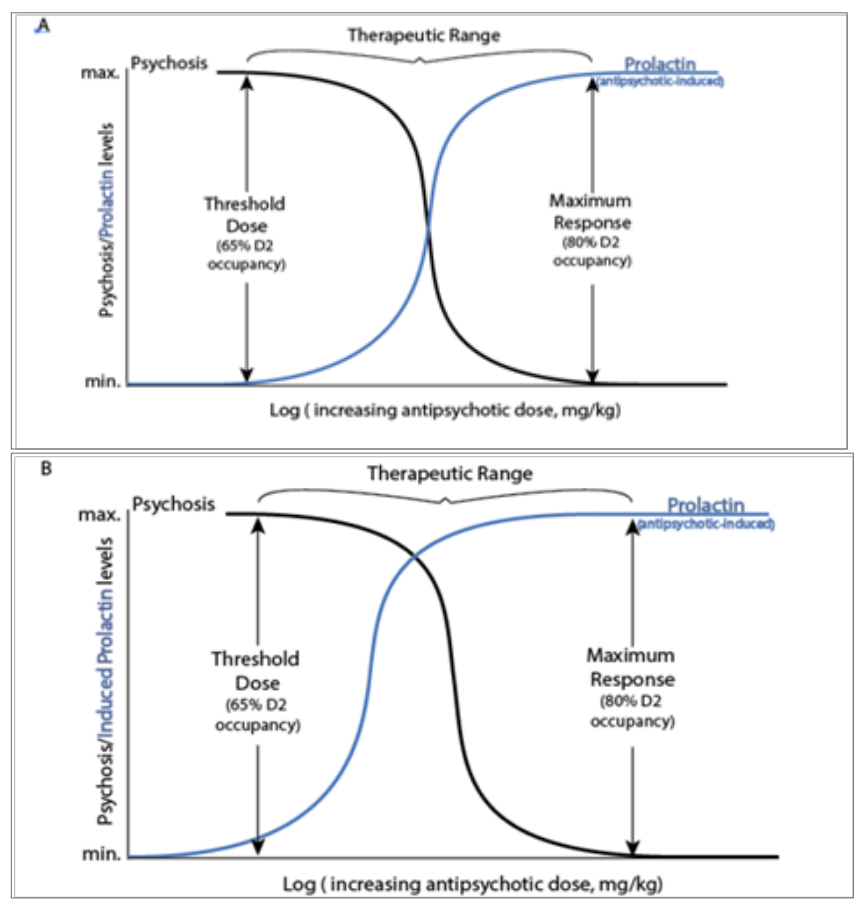

Figure 2 (A) Hypothetical dose-response curves. Depiction dose-response curves with similar threshold doses where antipsychotic effect occurs along with antipsychotic-induced prolactin secretion in the plasma. (B) Depiction of dose-response curves where the threshold of antipsychotic-induced prolactin secretion occurs before the threshold dose of antipsychotic effect.

Peripheral prolactin levels were associated with peripheral levels of some antipsychotic medications. ${ }^{58,59}$ Prolactin levels were associated with D2 occupancy as determined by PET scan after taking haloperidol ${ }^{60}$ and positively associated with D2 striatal occupancy in humans. In rats, D2 receptor occupancy of the striatum and pituitary was correlated $1 \mathrm{hr}$ after administering $0.01-2.5 \mathrm{mg} / \mathrm{kg}$ doses of olanzapine, $0.04-40 \mathrm{mg} / \mathrm{kg}$ of risperidone, and $0.16-40 \mathrm{mg} / \mathrm{kg}$ of quetiapine.

\section{Domperidone and amisulpride}

The lactotroph cells of the anterior pituitary are accessible and respond with prolactin release to D2 antagonists acting peripherally including domperidone that does not readily cross the blood-brain barrier (BBB) ${ }^{61-63}$ Despite the fact that the pituitary is vascularized by peripheral blood, antipsychotics may be at comparable concentrations to other brain regions because antipsychotics readily cross the BBB with the exception of amisulpride ${ }^{64}$ brain regions are highly vascular may have similar propensities to bind lipophilic drugs, and many regions of the brain are secondary sites for prolactin synthesis and may also be under dopamine control. For amisulpride, prolactin levels are not correlated with central D2/D3 occupancy or plasma levels of drug possibly because pituitary D2/D3 occupancy is saturated while central D2/D3 levels are not. ${ }^{65,66}$

The fact that amisulpride plasma levels were associated with D2/D3 occupancy in the striatum, thalamus and temporal cortex $(\mathrm{r}=0.83-0.87, \mathrm{p}<0.05)$ is consistent with the theory that peripheral biomarkers may be useful even for drugs like amisulpride with restricted $\mathrm{BBB}$ permeation as long as scale of assessment is linear throughout the dose range and does not plateau due to the high D2 occupancy in the periphery. ${ }^{66}$

\section{Risperidone}

Risperidone causes a rapid and persistent elevation of prolactin levels. Unlike amisulpride, which has a striatal to pituitary potency ratio of 654, risperidone's ratio of 14 is closer to quetiapine's ratio of 6 in rats. ${ }^{65}$ Serum levels of risperidone's primary metabolite, 9$\mathrm{OH}$-risperidone, is significantly correlated with prolactin levels $(\mathrm{r}=0.52, \mathrm{n}=25, \mathrm{p}=0.008)$ while levels ofrisperidone were not $(\mathrm{r}=0.23$, $\mathrm{p}=0.26) .{ }^{67}$ Although both risperidone and 9-OH-risperidone, which is commercially available as paliperidone, have similar affinities to D2 receptors, 9-OH-risperidone has a lower brain/plasma ratio and a half-life of 20 hours in contrast to risperidone's 2-4 hrs half-life. Prolactin levels were weakly correlated with $\sim 4-6 \mathrm{mg}$ /day daily dose of risperidone $(\mathrm{r}=0.328, \mathrm{p}=0.001)$ and showed a trend towards being weakly associated with improvement of in psychosis assessed at baseline without treatment for 2-4 weeks and then again at 12 weeks of risperidone treatment $(\mathrm{r}=-0.329-0.51, \mathrm{p}=0.016-0.094) .{ }^{40,41}$ Prolactin levels peaked within 2-4 weeks while BPRS scores continued to improve over the entire 12 weeks. ${ }^{41}$

\section{Haloperidol}

Early use of high doses of haloperidol and saturating prolactin response has been invoked as contributing to the conflicting reports concerning prolactin level correlation with clinical response ${ }^{68}$ and Chou et al. found prolactin levels were correlated with positive symptom improvement in 4 women and 19 men experiencing acute psychosis upon hospitalization who were medication free for at least 6 days then treated with $15 \mathrm{mg}$ /day resulting in plasma levels of $6.6+/-4.7 \mathrm{ng} / \mathrm{ml}(\mathrm{r}=-0.54, \mathrm{p}=0.008) .{ }^{68}$ An earlier study with $0.25 \mathrm{mg} /$ $\mathrm{kg} /$ day haloperidol found a correlation between the ratio of prolactin to homovanillic acid, a principal dopamine metabolite, and patient improvement in positive symptoms in 22 men and 16 women after only 4 days of treatment; participants were diagnosed with either SZ or schizophreniform disorder and were medication free 4 months at baseline ( $\mathrm{r}=-0.52$ in women and $\mathrm{p}=-0.42$ in both men and women combined, $\mathrm{p}=0.006){ }^{69}$

\section{Olanzapine}

D2 occupancy in the pituitary is closely correlated with D2 occupancy in the striatum in rats over the $60-96.5 \%$ occupancy range shown to be efficacious in humans (Table 1). Decreases in prolactin levels were associated with improvement of positive symptoms $(\mathrm{p}=0.002)$ in 36 men and 24 women with the diagnosis of SZ who had stopped taking antipsychotics at least 7 days before starting 3 months of treatment with olanzapine at $10-30 \mathrm{mg} /$ day. ${ }^{70}$ Subjects were previously taking olanzapine, ${ }^{27}$ first-generation antipsychotic, ${ }^{18}$ risperidone, ${ }^{12}$ clozapine, ${ }^{2}$ or quetiapine. ${ }^{1}$ Serum prolactin levels were $41.63+/-23.63 \mathrm{ng} / \mathrm{ml}$ at baseline and reached their lowest levels in the second month at $25.72+/-16.77 \mathrm{ng} / \mathrm{ml}$.

\section{Timing of prolactin assessment}

Serum prolactin levels were monitored within hours of administering antipsychotic medication in the de Visser et al study that identified a significant effect with antipsychotics doses (Table 1).54,71,72 Ideally biomarker assessment should occur when levels of drug reach steady-state concentrations and levels centrally are correlated with peripheral levels around 4-5 half-lives after a change in dose as is done with blood levels of lithium. ${ }^{1}$ It should be determined if antipsychotic levels in early treatment are correlated with steady-state levels. Plasma levels of both haloperidol and the active haloperidol 
metabolite added together are correlated with D2 occupancy (r2 $=0.84)$ at 12-14 hrs after their last dose maintained over a week. ${ }^{73}$

Unlike most second-generation antipsychotics with a half-life of $<3$ days that reach a steady state within 2 weeks, the half-life of haloperidol is 3 weeks and reaches steady-state concentrations after 100 days. $^{1}$ Prolactin levels rise within 30 minutes of administering haloperidol, beginning to level off in males at 60 minutes and $>90-120$ minutes in females. Peak prolactin levels are reached around 10 days and remain elevated from baseline even 20 weeks from administering haloperidol or risperidone. ${ }^{37}$ Prolactin levels peak then decline to a stable level after 4 months that is maintained for years of extended antipsychotic use. ${ }^{74}$

Peripheral prolactin levels are associated with D2 occupancy of some antipsychotic medications. ${ }^{58,59}$ Prolactin levels are correlated with D2 occupancy after 50\% occupancy is reached. ${ }^{75}$ For example, while determining the transient D2 occupancy tested at 1, 2.5 and 20 hours after an initial dose of quetiapine, D2 occupancy levels were noted to peak at $2.5 \mathrm{hrs}(62 \%)$ and were correlated with prolactin levels $(\mathrm{r} 2=0.8)$ and plasma levels $(\mathrm{r} 2=0.96)$; after 4 weeks when levels of quetiapine peaked prolactin levels were elevated, but at 12 weeks of treatment prolactin levels were normal. ${ }^{59}$ While investigating the mechanism of increased prolactin response to 2-20 $\mathrm{mg} /$ day of haloperidol, prolactin levels were found correlated with D2 occupancy ( $\mathrm{r}=0.45-0.5) .{ }^{58}$ However, a study of rats receiving risperidone and amisulpride found that D2 occupancy in the pituitary is higher than in the striatum. Although antipsychotics readily cross the $\mathrm{BBB}$, functional genetic variation and environmental influences in BBB efflux (P-glycoprotein) or transporters may contribute to interindividual differences in the proportion of antipsychotic centrally relative to peripheral levels. ${ }^{76}$

Finally, to be an effective biomarker of treatment response, the range of effective prolactin levels would have to be determined for each drug because of differences in D2 and 5-HT receptor affinity. Prolactin levels have been correlated with serotonin levels in 25 healthy controls $(\mathrm{r}=0.48, \mathrm{P}<0.05)^{77}$ and levels appear to be partially regulated by serotonin as shown by 5-HT antagonists decrease PRL levels. ${ }^{78}$ Alternately, individual dose-response curves could be generated while the patient's dose is titrated in order to identify the point of therapeutic efficacy.

\section{Conclusions}

There are several limitations in using prolactin levels as a biomarker of antipsychotic-response including:

a) The anterior pituitary is a circumventricular organ and prolactin is released in response to free antipsychotic in the peripheral blood as shown by the D2 antagonist, domperidone, that does not readily cross the blood brain barrier. ${ }^{63}$

b) Serum prolactin levels are influenced by several neurotransmitters in addition to dopamine.

c) Hyperprolactinemia is induced by antipsychotics with moderate to high affinity for D2 receptors; 4) it is not known whether measuring prolactin levels would be better than measuring the free levels of antipsychotics in the serum; and prolactin may be induced at low doses of antipsychotics. ${ }^{72}$

There may be a number of potential advantages to using a biomarker like prolactin that is released in response to D2 receptor antagonist and DA agonist occupancy. While smoking, absorption and genetic factors of cytochrome P450 enzymes that contribute to individual differences in the breakdown of antipsychotics in the liver ${ }^{79,80}$ would be accounted for by measuring either plasma levels or prolactin levels, measuring prolactin levels takes into account individual conditions that may change the free fraction of drug circulating, ${ }^{1}$ an individual's genetic and environmental factors that contribute to the numbers of D2 receptors available such as upregulation of receptors in response to antipsychotic drugs. In addition, measuring prolactin levels is inexpensive, may be useful for determining the minimal dose of antipsychotics, and a single test would take into account all the active metabolites. Multiple tests throughout dose titrations might allow generation of a person's specific dose response which might allow prediction of a personal lowest efficacious dose of a specific antipsychotic medication instead of relying solely on data generated for a population. There is inter-individual variability in D2 receptor density that appears to be affected in part by age ${ }^{81,82}$ and having a biomarker that is in a regulatory feedback loop may account for changes in D2 receptor density and occupancy. ${ }^{83-95}$

\section{Acknowledgments}

None.

\section{Conflict of interest}

Author declares no conflict of interest.

\section{References}

1. Janicak PG, SR Marder, MN Pavuluri. Pharmacodynamics and Pharmacokinetics, In: C Mitchell, editor. Principles and Practice of Psychopharmacotherapy. Wolters Kluwer, Lippincott Williams \& Wilkins: Philadelphia; 2011:77-180.

2. Robinson DG, MG Woerner, B Napolitano, et al. Randomized comparison of olanzapine versus risperidone for the treatment of first-episode schizophrenia: 4-month outcomes. Am J Psychiatry. 2006;163(12):20962102 .

3. Agid O, T Arenovich, G Sajeev, et al. An algorithm-based approach to first-episode schizophrenia: response rates over 3 prospective antipsychotic trials with a retrospective data analysis. J Clin Psychiatry. 2011;72(11):1439-1444.

4. Davis JM, CB Schaffer, GA Killian, et al. Important issues in the drug treatment of schizophrenia. Schizophr Bull. 1980;6(1):70-87.

5. Schooler N, J Rabinowitz, M Davidson, et al. Risperidone and haloperidol in first-episode psychosis: a long-term randomized trial. Am J Psychiatry. 2005;162(5):947-953.

6. Lieberman JA, TS Stroup, JP McEvoy, et al. Effectiveness of antipsychotic drugs in patients with chronic schizophrenia. $N$ Engl J Med. 2005;353(12):1209-1223.

7. Swartz MS, DO Perkins, TS Stroup, et al. Effects of antipsychotic medications on psychosocial functioning in patients with chronic schizophrenia: findings from the NIMH CATIE study. Am J Psychiatry. 2007; 164(3):428-436.

8. Jones PB, TR Barnes, L Davies, et al. Randomized controlled trial of the effect on Quality of Life of second-vs first-generation antipsychotic drugs in schizophrenia: Cost Utility of the Latest Antipsychotic Drugs in Schizophrenia Study (CUtLASS 1). Arch Gen Psychiatry. 2006;63(10):1079-1087.

9. Leucht S, C Corves, D Arbter, et al. Second-generation versus first generation antipsychotic drugs for schizophrenia: a meta-analysis. Lancet. 2009;373(9657):31-41. 
10. Csernansky JG, R Mahmoud, R Brenner. A comparison of risperidone and haloperidol for the prevention of relapse in patients with schizophrenia. $N$ Engl J Med. 2002;346(1):16-22.

11. Potkin SG, R Bera, B Gulasekaram, et al. Plasma clozapine concentrations predict clinical response in treatment-resistant schizophrenia. J Clin Psychiatry. 1994;55(Suppl B):133-136.

12. Routledge PA. The plasma protein binding of basic drugs. Br J Clin Pharmacol. 1986;22(5):499-506.

13. Burrows GD, T. Norman, B Davies. Antimanics, anticonvulsants, and other drugs in psychiatry: Drugs in psychiatry. Elsevier. New York, NY, USA, 1987;4:451.

14. Janicak PG, SR Marder, MN Pavuluri. Treatment with Antipsychotics, In C Mitchell, editor. Principles and Practice of Psychopharmacotherapy, Wolters Kluwer, Lippincott Williams \& Wilkins: Philadelphia; 2011:77180 .

15. Hasegawa M, R Gutierrez Esteinou, L Way, et al. Relationship between clinical efficacy and clozapine concentrations in plasma in schizophrenia: effect of smoking. J Clin Psychopharmacol. 1993;13(6):383-390.

16. Kronig MH, RA Munne, S Szymanski, et al. Plasmaclozapine levels and clinical response for treatment-refractory schizophrenic patients. Am J Psychiatry. 1995;152(2):179-182.

17. Perry PJ, DD Miller, SV Arndt, et al. Cadoret, Clozapine and norclozapine plasma concentrations and clinical response of treatment-refractory schizophrenic patients. Am J Psychiatry. 1991;148(2):231-235.

18. Friesen HG. The discovery of human prolactin: a very personal account. Clin Invest Med. 1995;18(1):66-72.

19. Trimble MR, MM Perez, RTC Pratt. Some Uses of Prolactin in Psychiatry. In: J Mendlewicz, HM van Praag, editors. Psychoneuroendocrinology and Abnormal Behavior. National Library of Medicine: Basel, 1980;46-57.

20. Bole Feysot C, V Goffin, M Edery, et al. Prolactin (PRL) and its receptor: actions signal transduction pathways and phenotypes observed in PRL receptor knockout mice. Endocr Rev. 1998;19(3):225-268.

21. Kleinberg DL, W Niemann, E Flamm, et al. Primate mammary development. Effects of hypophysectomy, prolactin inhibition, and growth hormone administration. J Clin Invest. 1985;75(6):1943-1950.

22. Freeman ME, B Kanyicska, A Lerant, et al. Prolactin: structure, function, and regulation of secretion. Physiol Rev. 2000;80(4):1523-1631.

23. McPherson R, M Pincus. Henry's clinical diagnosis and management by laboratory methods. 21st ed. WB Saunders, editor. Philadelphia; 2006.

24. Madhusoodanan S, S Parida, C Jimenez. Hyperprolactinemia associated with psychotropics-a review. Hum Psychopharmacol. 2010;25(4):281297.

25. Liu I.S, SR.George, P Seeman. The human dopamine D2(Longer) receptor has a high-affinity state and inhibits adenylyl cyclase. Brain Res Mol Brain Res. 2000;77(2):281-284.

26. Centonze D, A Usiello, P Gubellini, et al. Dopamine D2 receptor mediated inhibition of dopaminergic neurons in mice lacking D2L receptors. Neuropsychopharmacology. 2002;27(5):723-726.

27. Agid O, D Mamo, N Ginovart, et al. Striatal vs extrastriatal dopamine D2 receptors in antipsychotic response-a double-blind PET study in schizophrenia. Neuropsychopharmacology. 2007;32(6):1209-1215.

28. Stone JM, JM Davis, S Leucht, et al. Cortical dopamine D2/D3 receptors are a common site of action for antipsychotic drugs-an original patient data meta-analysis of the SPECT and PET in vivo receptor imaging literature. Schizophr Bull. 2009;35(4):789-797.
29. Epstein J, E Stern, D Silbersweig. Mesolimbic activity associated with psychosis in schizophrenia. Symptom-specific PET studies. Ann N Y Acad Sci. 1999;877:562-574.

30. Lidow MS, GV Williams, PS Goldman Rakic. The cerebral cortex: a case for a common site of action of antipsychotics. Trends Pharmacol Sci. 1998;19(4):136-140.

31. Joyce JN, JH Meador Woodruff. Linking the family of D2 receptors to neuronal circuits in human brain: insights into schizophrenia. Neuropsychopharmacology. 1997;16(6):375-384.

32. Seeman P. Targeting the dopamine D2 receptor in schizophrenia. Expert Opin Ther Targets. 2006;10(4):515-531.

33. Hall H, G Sedvall, O Magnusson, et al. Distribution of D1- and D2dopamine receptors, and dopamine and its metabolites in the human brain. Neuropsychopharmacology. 1994;11(4):245-256.

34. Peuskens J, L Pani, J Detraux, et al. The effects of novel and newly approved antipsychotics on serum prolactin levels: a comprehensive review. CNS Drugs. 2014;28(5):421-453.

35. Kessler RM, WO Whetsell, MS Ansari, et al. Identification of extrastriatal dopamine D2 receptors in post mortem human brain with [125I] epidepride. Brain Res. 1993;609(1-2):237-243.

36. Kathleen Deska Pagana, Timothy J. Pagana. Mosby's Manual of Diagnostic and Laboratory Tests. 4th ed. St Louis: Mosby Elsevier, 2010.

37. Kinon BJ, JA Gilmore, H Liu, et al. Hyperprolactinemia in response to antipsychotic drugs: characterization across comparative clinical trials. Psychoneuroendocrinology. 2003;28(Suppl 2):69-82.

38. Kinon BJ, JA Gilmore, H Liu, et al. Prevalence of hyperprolactinemia in schizophrenic patients treated with conventional antipsychotic medications or risperidone. Psychoneuroendocrinology. 2003;28(Suppl 2):55-68.

39. Garcia Rizo C, E Fernandez Egea, C Oliveira, et al. Prolactin concentrations in newly diagnosed, antipsychotic-naive patients with nonaffective psychosis. Schizophr Res. 2011;134(11):16-19.

40. Zhang XY, DF Zhou, CL Yuan, et al. Risperidone-induced increase in serum prolactin is correlated with positive symptom improvement in chronic schizophrenia. Psychiatry Res. 2002;109(3):297-302.

41. Lee BH, YK Kim. The relationship between prolactin response and clinical efficacy of risperidone in acute psychotic inpatients. Prog Neuropsychopharmacol Biol Psychiatry. 2006;30(4):658-662.

42. Schwarz E, R Izmailov, M Spain, et al. Validation of a blood based laboratory test to aid in the confirmation of a diagnosis of schizophrenia. Biomark Insights. 2010;12(5):39-47.

43. Krishnamurthy D, LW Harris, Y Levin, et al. Metabolic, hormonal and stress-related molecular changes in post-mortem pituitary glands from schizophrenia subjects. World J Biol Psychiatry. 2013;14(7):478-489.

44. Malik P, G Kemmler, M Hummer, et al. Sexual dysfunction in first-episode schizophrenia patients: results from European first episode schizophrenia trial. J Clin Psychopharmacol. 2011;31(3):274-280.

45. Buchanan RW, J Kreyenbuhl, DL Kelly, et al. The 2009 schizophrenia PORT psychopharmacological treatment recommendations and summary statements. Schizophr Bull. 2010;36(1):71-93.

46. Clemens JA, EB Smalstig, BD Sawyer. Antipsychotic drugs stimulate prolactin release. Psychopharmacologia. 1974;40(2):123-127.

47. Clemens JA, CJ Shaar, EB Smalstig, et al. Effects of some psychoactive agents on prolactin secretion in rats of different endocrine states. Horm Metab Res. 1974;6(3):187-190. 
48. Asnis GM, EJ Sachar, G Langer, et al. Prolactin responses to haloperidol in normal young women. Psychoneuroendocrinology. 1988;13(6):515-520.

49. Wong J, MV Seeman. Prolactin, menstrual irregularities, quality of life. Schizophr Res. 2007;91(1-3):270-271.

50. Brown WA. Prolactin levels and effects of neuroleptics. Psychosomatics. 1983;24(6):569-581.

51. Lee SA, CA Haiman, NP Burtt, et al. A comprehensive analysis of common genetic variation in prolactin (PRL) and PRL receptor (PRLR) genes in relation to plasma prolactin levels and breast cancer risk: the multiethnic cohort. BMC Med Genet. 2007;8(72).

52. Souza RP, HY Meltzer, JA Lieberman, et al. Prolactin as a biomarker for treatment response and tardive dyskinesia in schizophrenia subjects: old thoughts revisited from a genetic perspective. Hum Psychopharmacol. 2011;26(1):21-27.

53. Veselinovic T, H Schorn, IB Vernaleken, et al. Impact of Differen Antidopaminergic Mechanisms on the Dopaminergic Control of Prolactin Secretion. J Clin Psychopharmacol. 2011;31(2):214-220.

54. de Visser SJ, J van der Post, MSM Pieters, et al. Biomarkers for the effects of antipsychotic drugs in healthy volunteers. British Journal of Clinical Pharmacology. 2001;51(2):119-132.

55. Kahn RS, WW Fleischhacker, H Boter, et al. Effectiveness of antipsychotic drugs in first-episode schizophrenia and schizophreniform disorder: an open randomised clinical trial. Lancet. 2008;371(9618):1085-1097.

56. Shim JC, JG Shin, DL Kelly, et al. Adjunctive treatment with a dopamine partial agonist, aripiprazole, for antipsychotic-induced hyperprolactinemia: a placebocontrolled trial. Am J Psychiatry. 2007;164(9):1404-1410.

57. Bushe C, M Shaw, RC Peveler. A review of the association between antipsychotic use and hyperprolactinaemia. $J$ Psychopharmacol. 2008;22(2 Suppl):46-55.

58. Daskalakis Z, B Christensen, R Zipursky, et al. Relationship between D2 occupancy and prolactin levels in first episode psychosis. Biol Psychiatry. 1998;43(8):S113.

59. Tauscher Wisniewski S, S Kapur, J Tauscher, et al. Quetiapine: an effective antipsychotic in first-episode schizophrenia despite only transiently high dopamine-2 receptor blockade. J Clin Psychiatry. 2002;63(11):992-997.

60. Kapur S, R Zipursky, C Jones, et al. Relationship between dopamine D(2) occupancy, clinical response, and side effects: a double-blind PET study of first-episode schizophrenia. Am J Psychiatry. 2000;157 (4):514-520.

61. Nerozzi D, A Magnani, C Dastoli, et al. Prolactin responses to domperidone in chronic schizophrenia. Psychiatry Res. 1992;42(2):159-169.

62. Nerozzi D, A Magnani, V Sforza, et al. Plasma prolactin response to domperidone in acute schizophrenia and schizophreniform illness. Psychiatry Res. 1990;34(2):139-147.

63. Laduron PM, Leysen JE. Domperidone, a specific in vitro dopamine antagonist, devoid of in vivo central dopaminergic activity. Biochem Pharmacol. 1979;28(14):2161-2165.

64. Natesan S, GE Reckless, KB Barlow, et al. Amisulpride the 'atypical' atypical antipsychotic-Comparison to haloperidol, risperidone and clozapine. Schizophr Res. 2008;105(1-3):224-235.

65. Kapur S, X Langlois, P Vinken, et al. The differential effects of atypical antipsychotics on prolactin elevation are explained by their differential blood-brain disposition: a pharmacological analysis in rats. J Pharmacol Exp Ther. 2002;302(3):1129-1134.

66. Bressan RA, K Erlandsson, EP Spencer, et al. Prolactinemia is uncoupled from central D2/D3 dopamine receptor occupancy in amisulpride treated patients. Psychopharmacology(Berl). 2004;175(3):367-373.
67. Knegtering R, P Baselmans, S Castelein, et al. Predominant role of the 9-hydroxy metabolite of risperidone in elevating blood prolactin levels. Am J Psychiatry. 2005;162(5):1010-1012.

68. Chou JC, R Douyon, P Czobor, et al. Change in plasma prolactin and clinical response to haloperidol in schizophrenia and schizoaffective disorder. Psychiatry Res. 1998;81(1):51-55.

69. Davila R, MA Gonzalez, M Zumarraga, et al. Plasma prolactin and plasma homovanillic acid: predictors of clinical response in schizophrenia. Biol Psychiatry. 1995;38(4):267-269.

70. Chen DK, YT So, RS Fisher. Use of serum prolactin in diagnosing epileptic seizures: report of the Therapeutics and Technology Assessment Subcommittee of the American Academy of Neurology. Neurology. 2005;65(5):668-675.

71. Langer G, EJ Sachar, FS Halpern, et al. The prolactin response to neuroleptic drugs. A test of dopaminergic blockade: neuroendocrine studies in normal men. J Clin Endocrinol Metab. 1977;45(5):996-1002.

72. Gruen PG, EJ Sachar, N Altman, et al. Relation of plasma prolactin to clinical response in schizophrenic patients. Arch Gen Psychiatry. 1978;35(10):1222-1227.

73. Kapur S, R Zipursky, P Roy, et al. The relationship between D2 receptor occupancy and plasma levels on low dose oral haloperidol: a PET study. Psychopharmacology(Berl). 1997;131(2):148-152.

74. Brown WA, TP Laughren. Tolerance to the prolactin-elevating effect of neuroleptics. Psychiatry Res. 1981;5(3):317-322.

75. Nordstrom AL, L Farde. Plasma prolactin and central D2 receptor occupancy in antipsychotic drug-treated patients. J Clin Psychopharmacol. 1998;18(4):305-310

76. de Klerk OL, AT Willemsen, FJ.Bosker, et al. Regional increase in Pglycoprotein function in the blood-brain barrier of patients with chronic schizophrenia: a PET study with [(11)C]verapamil as a probe for Pglycoprotein function. Psychiatry Res. 2010;183(2):151-156.

77. Muck Seler D, N Pivac, M Mustapic, et al. Platelet serotonin and plasma prolactin and cortisol in healthy, depressed and schizophrenic women. Psychiatry Res. 2004;127(3):217-226.

78. Goodall EM, PJ Cowen, M Franklin, et al. Ritanserin attenuates anorectic, endocrine and thermic responses to d-fenfluramine in human volunteers. Psychopharmacology (Berl). 1993;112(4):461-466.

79. Jin Y, BG Pollock, K Coley, et al. Population pharmacokinetics of perphenazine in schizophrenia patients from CATIE: impact of race and smoking. J Clin Pharmacol. 2010;50(1):73-80.

80. Fleeman N, Y Dundar, R Dickson, et al. Cytochrome P450 testing for prescribing antipsychotics in adults with schizophrenia: systematic review and meta-analyses. Pharmacogenomics J. 2011;11(1):1-14.

81. Uchida H, S Kapur, BH Mulsant, et al. Sensitivity of older patients to antipsychotic motor side effects: a PET study examining potential mechanisms. Am J Geriatr Psychiatry. 2009;17(3):255-263.

82. Uchida H, BG Pollock, RR Bies, et al. Predicting age-specific dosing of antipsychotics. Clin Pharmacol Ther. 2009;86(4):360-362.

83. Lako IM, ER van den Heuvel, H Knegtering, et al. Estimating dopamine $\mathrm{D}(2)$ receptor occupancy for doses of 8 antipsychotics: a meta-analysis. $J$ Clin Psychopharmacol. 2013;33(5):675-681.

84. Grunder G, C Fellows, H Janouschek, et al. Brain and plasma pharmacokinetics of aripiprazole in patients with schizophrenia: an [18F] fallypride PET study. Am J Psychiatry. 2008;165(8):988-995.

85. Kane JM, TB Cooper, EJ Sachar, et al. Clozapine: plasma levels and prolactin response. Psychopharmacology (Berl). 1981;73(2):184-187. 
86. Kapur S, RB Zipursky, G Remington. Clinical and theoretical implications of 5-HT2 and D2 receptor occupancy of clozapine, risperidone, and olanzapine in schizophrenia. Am J Psychiatry. 1999;156(2):286-293.

87. Kapur S, G Remington, C Jones S, et al. 'Typical' vs. 'Atypical': Lessons from pet studies of 5-HT2 and D2 occupancy. Schizophrenia Research. 1997;24(1-2):167.

88. Kapur S, RB Zipursky, C Jones, et al. The D2 receptor occupancy profile of loxapine determined using PET. Neuropsychopharmacology. 1996;15(6):562-566.

89. Raedler TJ, MB Knable, T Lafargue, et al. In vivo determination of striata dopamine D2 receptor occupancy in patients treated with olanzapine. Psychiatry Res. 1999;90(2):81-90.

90. Kapur S, R Zipursky, C Jones, et al. A positron emission tomography study of quetiapine in schizophrenia: a preliminary finding of an antipsychotic effect with only transiently high dopamine D2 receptor occupancy. Arch Gen Psychiatry. 2000;57(6):553-559.
91. Kapur S, G Remington, RB Zipursky, et al. The D2 dopamine receptor occupancy of risperidone and its relationship to extrapyramidal symptoms: a PET study. Life Sci. 1995;57(10):PL103-107.

92. Daniel DG, LF Copeland. Ziprasidone: comprehensive overview and clinical use of a novel antipsychotic. Expert Opin Investig Drugs. 2000;9(4):819-828.

93. Stojilkovic SS, T Murano, AE Gonzalez Iglesias, et al. Multiple roles of $\mathrm{Gi} / \mathrm{o}$ protein-coupled receptors in control of action potential secretion coupling in pituitary lactotrophs. Ann N Y Acad Sci. 2009;1152:174-186.

94. Gonzalez Iglesias AE, T Murano, S Li, et al. Dopamine inhibits basal prolactin release in pituitary lactotrophs through pertussis toxin-sensitive and-insensitive signaling pathways. Endocrinology. 2008;149(4):1470 1479.

95. Masri B, A Salahpour, M Didriksen, et al. Antagonism of dopamine D2 receptor/beta-arrestin 2 interaction is a common property of clinically effective antipsychotics. Proc Natl Acad Sci U S A. 2008;105(36):1365613661. 